Article

\title{
Tintinnid Ciliate Communities in Pre- and Post-Winter Conditions in the Southern Adriatic Sea (NE Mediterranean)
}

\author{
Jakica Njire ${ }^{1, *}$, Mirna Batistić ${ }^{1}$, Vedrana Kovačević ${ }^{2}$ (I) Rade Garić $^{1}$ and Manuel Bensi ${ }^{2}$ (i) \\ 1 Institute for Marine and Coastal Research, University of Dubrovnik, Kneza Damjana Jude 12, \\ 20000 Dubrovnik, Croatia; mirna.batistic@unidu.hr (M.B.); rade.garic@unidu.hr (R.G.) \\ 2 Istituto Nazionale di Oceanografia e di Geofisica Sperimentale, Borgo Grotta Gigante 42-C, I-34010 Trieste, \\ Italy; vkovacevic@inogs.it (V.K.); mbensi@inogs.it (M.B.) \\ * Correspondence: jakica.njire@unidu.hr; Tel.: +385-20-323-449
}

Received: 21 August 2019; Accepted: 3 November 2019; Published: 7 November 2019

check for updates

\begin{abstract}
The Southern Adriatic Sea is a dynamic region under the influence of diverse physical forces that modify sea water properties as well as plankton dynamics, abundance, and distribution in an intricate way. The most pronounced being: winter vertical convection, lateral exchanges between coastal and open sea waters, and the ingression of water masses of different properties into the Adriatic. We investigated the distribution and abundance of tintinnid species in this dynamic environment in pre- and post-winter conditions in 2015/2016. A strong ingression of the saline Levantine Intermediate Water, supported by the cyclonic mode of the North Ionian Gyre in 2015 and 2016, in December was associated with a high diversity of oceanic species. An unusual spatial distribution of neritic-estuarine species Codonellopsis schabi was observed in deeper layers along the analyzed transect, which emphasizes the strong influence of physical processes on deep water biology in the South Adriatic. A shift of population toward greater depths (mesopelagic) and modification of deep sea community structure was recorded in April as a consequence of the winter convection-driven sinking of tintinnids. Our findings indicate that tintinnid abundance and composition is heavily influenced by physical conditions and they are good indicators of the impact of physical forces, including climate changes, on marine environment.
\end{abstract}

Keywords: microzooplankton; tintinnids; winter convection; water masses distribution; Adriatic Sea; Mediterranean Sea

\section{Introduction}

Tintinnid ciliates are a common component of planktonic communities and they are present in all of the world's oceans [1,2]. Tintinnids and pelagic ciliates are generally significant consumers of pico- and nano-plankton [3,4] and are, in turn, exploited by higher trophic levels [5]. The importance of protozoan grazing and carbon budget recycling in the oceans has been established [6,7]. The 'changing paradigm' of planktonic food webs has focused significant attention on microbial populations, and tintinnids have been identified as ideal organisms for studying changes in the structure and composition of microzooplankton $[8,9]$. Their distribution is related to hydrographical conditions and they have been used as indicators of upwelling [2]. This makes them ideal candidates for an investigation of the effects of physical forcings on zooplankton communities. The first investigation of vertical distribution of tintinnids in the open South Adriatic was conducted in June 1978 [10], after which there were further studies in 1979/1980 [11] and 1985-1990 [12-14]. All of the investigations of tintinnid vertical distribution in the open southern Adriatic were done by using $53-\mu \mathrm{m}$ zooplankton nets. Since 1990 there have been no investigations of vertical distribution of open sea tintinnids in the Adriatic Sea and 
such studies were rare, even in the Mediterranean generally and concentrated on tintinnid distribution up to $250 \mathrm{~m}$ depth $[9,15,16]$.

The southern Adriatic is a unique area that is influenced by various physical forces as well as incoming water masses of different properties through the Strait of Otranto. During winter it is subjected to spells of dry and cold NE bura winds, which induce vertical convection in the South Adriatic Pit (SAP) [17], triggering open sea winter blooms [18-21], and in parallel dense water formations in the shallow northern Adriatic. The North Adriatic Dense Water (NAdDW) then travels southwards and fills the SAP, bringing with it different species from the north [22]. A prominent feature of Adriatic circulation is its cyclonic surface flow, the Eastern Adriatic Current (EAC), which carries into the Adriatic warm and salty waters from the Ionian Sea and Levantine basin, thus compensating for the outflow of less saline water, being transported by the Western Adriatic Current (WAC) along the western Adriatic margin [23,24], and the outflow of the Adriatic Dense Water (AdDW) [25]. The Po River is the main freshwater discharge into the Adriatic. Its plume is transported along the western (Italian) coastline as a major upper component of the WAC [26]. Moreover, Adriatic water properties are modified on decadal scale by the inflow of different water masses from the Mediterranean. This phenomenon is under the influence of the circulation of the North Ionian Gyre (NIG) [27]. During the cyclonic period, the NIG brings more salty and warm waters from the eastern Mediterranean (Levantine Intermediate Water-LIW) and during the anticyclonic phase less salty Atlantic Waters from western Mediterranean are advected. The NIG is in a negative feedback relationship with the Adriatic Sea and the mechanism by which it changes its direction on a decadal scale is called the BiOS mechanism [27]. By modifying the properties of Adriatic water by the advection of different water masses through the Strait of Otranto, the BiOS mechanism can influence the intensity of phytoplankton blooms and production in the Adriatic [21,28-30], as well as the ingression of new species [28,31-36].

The aim of the study is to discuss the influence of complex dynamics that are associated with physical factors (e.g., vertical mixing, lateral exchanges) on the distribution and abundance of tintinnids in a unique system, such as the southern Adriatic. We test the hypothesis that surface tintinnid species found in the deep layers during the post convective phase can survive for a long time, changing the composition of local deep sea fauna. Here, special attention is given to the lateral exchanges between coastal and open sea waters and how physical forces modify species composition and abundance in the deep sea. The effect of the open-ocean winter convection on the zooplankton community throughout the water column is still poorly studied in the Mediterranean Sea, especially for deep sea communities [31].

\section{Material and Methods}

Two oceanographic surveys on-board R/V Bios dva were conducted in the SA along the Dubrovnik-Bari transect (Figure 1): in December 2015 (from 10th to 15th) and in April 2016 (from 5th to 10th). The oceanographic data were collected in the framework of a research Eurofleets2 campaign, named ESAW (Evolution and Spreading of the Southern Adriatic Waters). The water samples were collected at thirteen stations (max sampling depth in parentheses): ESAW-01 (110 m), ESAW-02 (130 m), ESAW-03 (490 m), ESAW-04 (700 m), ESAW-05 (900 m), ESAW-06 (1000 m), ESAW-07 (1100 m), ESAW-08 (1150 m), ESAW-09 (1200 m), ESAW-10 (1100 m), ESAW-11 (900 m), ESAW-12 (300 m), and ESAW-13 $(160 \mathrm{~m})$, which were located along the central transect of the SA, and at the fourteenth station ESAW-GG (810 m depth), which was located in the northwestern periphery of the SA (Figure 1). The samples for zooplankton were taken at stations marked with red dots (Figure 1). Table 1 presents the collected samples. 


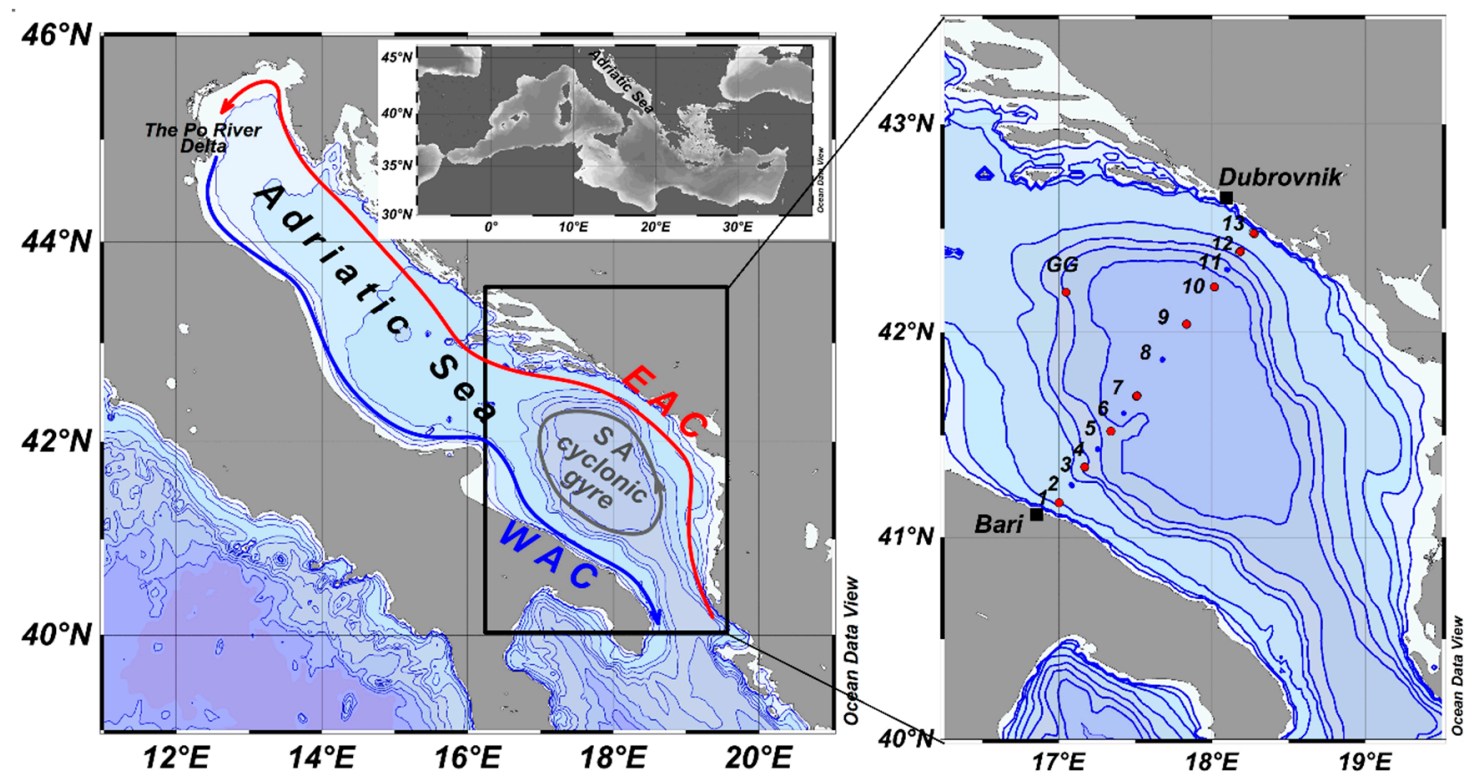

Figure 1. The Adriatic Sea (with an inset map of the Mediterranean Sea): principal circulation patterns at basin- and sub-basin scales (left panel). A detail of the Southern Adriatic (SA) with hydrological stations and zooplankton sampling locations marked with red dots (right panel). The blue lines indicate the following isobaths: 25, 50, 100, 250, 500, 750, and 1000 m. EAC: Eastern Adriatic Current, WAC: Western Adriatic Current.

Table 1. List of samples collected in the southern Adriatic in December 2015 and April 2016.

\begin{tabular}{|c|c|c|c|c|c|c|c|c|c|}
\hline \multirow[b]{2}{*}{$\begin{array}{l}\text { Depth } \\
\text { Layers }\end{array}$} & \multicolumn{9}{|c|}{ Stations } \\
\hline & 1 & 3 & 5 & 7 & $9 *$ & $10 * *$ & 12 & 13 & GG \\
\hline $0-50$ & $x$ & & $X$ & & $X^{*}$ & $X * *$ & $X$ & $X$ & $X$ \\
\hline 50-100 & $x$ & & $x$ & & $X^{*}$ & $X * *$ & $x$ & $x$ & $X$ \\
\hline 0-100 & & $X$ & & $X$ & & & & & \\
\hline $100-200$ & & $x$ & $x$ & & $X^{*}$ & $X^{* *}$ & $X$ & & $X$ \\
\hline $200-300$ & & & $x$ & & $X^{*}$ & $X * *$ & $x$ & & $x$ \\
\hline $300-400$ & & & $X^{*}$ & & $X^{*}$ & $X * *$ & & & $X$ \\
\hline $400-600$ & & & $X^{*}$ & & $X^{*}$ & $X * *$ & & & \\
\hline $600-800$ & & & $X^{*}$ & & $X^{*}$ & $X^{* *}$ & & & \\
\hline $1200-800$ & & & & & $X^{*}$ & $X * *$ & & & \\
\hline
\end{tabular}

${ }^{*}$ sampled only in December, ${ }^{* *}$ sampled only in April.

The profiles of temperature, salinity, chlorophyll- $a$ (Chl-a) fluorescence, and dissolved oxygen (DO) concentration (averaged over 1-dbar intervals) were taken by a CTD (Conductivity-Temperature-Depth) multiparametric probe SBE911 plus (SEA Bird Electronics Inc., USA) that was equipped with a WETLabs Fluorescence sensor and SBE43 oxygen sensor. Potential temperature $(\theta)$ was calculated with reference to 0 dbar. The fluorescence sensor (WETLabs fluorometer) was factory calibrated on a Thalassiosira weissflogii monoculture.

The samples for zooplankton identification were collected by vertical hauls of a Nansen opening-closing net with $53-\mu \mathrm{m}$ mesh ( $51 \mathrm{~cm}$ diameter, $250 \mathrm{~cm}$ length) that historically has been used in the Adriatic for investigations of tintinnid vertical distribution in the open sea [11-14]. The 53- $\mu \mathrm{m}$ plankton net is suitable, because it captures larger species when considering that smaller tintinnid species are rare in open waters of the southern Adriatic, as demonstrated by investigations with a 250-1 "Adriatic" plankton trap [37]. Thus, the presented data still permit a valuable quantitative description of the relative abundance relationships of tintinnids over space and time. As station depth permitted, 
the following sampling intervals were used: 0-50, 50-100, 100-200, 200-300, 300-400, 400-600, 600-800, and $800-1200 \mathrm{~m}$. The samples were preserved in a $2.5 \%$ formalin-seawater solution buffered with $\mathrm{CaCO}_{3}$. Counting and taxonomic identification of the microzooplankton was performed with an Olympus inverted microscope at $100 \times$ and $400 \times$ magnifications. Sub-samples of $1 / 32$ of the samples were placed in a glass cell (dimensions $7 \times 4.5 \times 0.5 \mathrm{~cm}$ ) and examined for common species, while the entire catch was examined for rare species. The abundance of tintinnids is presented as the number of specimens per cubic meter (ind. $\mathrm{m}^{-3}$ ).

The dominant species in this paper are defined as those that fulfill the following abundance and frequency criteria in the following depth strata: $0-100 \mathrm{~m}\left(\geq 100\right.$ ind. $\mathrm{m}^{-3}$ in at least $20 \%$ of samples) $100-400 \mathrm{~m}$ ( $\geq 10$ ind. $\mathrm{m}^{-3}$ in at least $20 \%$ of samples), $400-1200 \mathrm{~m}\left(\geq 5\right.$ ind. $\mathrm{m}^{-3}$ in at least $20 \%$ of samples), with a frequency of occurrence of $\geq 20 \%$ in the total number of samples.

Tintinnid identifications were based on lorica morphology while using taxonomic references [38,39]. Only complete lorica or lorica with plasmatic body parts were considered for quantitative analysis.

The tintinnid species that were found in this research were classified according to their spatial distribution as oceanic, neritic-estuarine, surface, subsurface, mesopelagic, and deep-sea species based on the relevant literature [12-14,39].

Principal component analysis (PCA) was conducted by using a software package PC-ORD 5.10 for Windows. For PCA, the environmental variables included seawater temperature, salinity, Chl- $a$, depth and dissolved oxygen concentration, while biological variables consisted of the abundance of 14 dominant tintinnid species. Analysis attempts were made to identify the patterns that explain the major variation within data.

Non-parametric Spearman rank order correlations were used to assess the influence of the environmental variables on the tintinnid abundance for each sampling period separately by using STATISTICA (data analysis software system) version 8.0 (2007), StatSoft, Inc., Tulsa, USA.

\section{Results}

\subsection{Hydrography, Dissolved Oxygen and Chlorophyll $A$}

In December 2015, the potential temperature $(\theta)$ in the surface layer (upper $100 \mathrm{~m}$ ), increasing from the western toward the eastern shelf, varied in a range between 14.59 and $18.12^{\circ} \mathrm{C}$. The average $\theta$ below $100 \mathrm{~m}$ was $14.47 \pm 0.43^{\circ} \mathrm{C}$. The maximum $\theta$ of $18.12^{\circ} \mathrm{C}$ was measured near the eastern shelf break. A warm layer extended down to $70 \mathrm{~m}$ depth. A minimum $\theta$ value of $13.09^{\circ} \mathrm{C}$ was recorded in the deepest layer at station ESAW-09 (Figure 2). In April 2016, the surface layer was colder and $\theta$ varied in a range between $14.46^{\circ} \mathrm{C}$ and $17.17^{\circ} \mathrm{C}$. $\theta$ steadily decreased with increasing depth, and the minimum value of $13.09^{\circ} \mathrm{C}$ was observed again at the deepest level of ESAW-09 (see Figure 2).

Overall, the vertical distribution of the thermohaline properties at station ESAW-GG (Figure 2c,f) were very similar to those that were observed at other deep offshore stations in the SA, such as ESAW-07, ESAW-08, ESAW-09, and ESAW-10. The lowest salinity values, around 38.74/38.77, in December/April, respectively, were observed in the bottom layer. CTD profiles that were gathered at GG station revealed a slight increase in $\theta$ in the deep layer in April when compared to December, and an overall increase in salinity in the entire water column, with the disappearance of a subsurface double salinity maximum (at $\sim 70 \mathrm{~m}$ and at $\sim 500 \mathrm{~m}$ depth) registered in December 2015.

During both periods, salinity in the upper layer was lower near the shore than in the open sea. The most pronounced minima, around 36.98/37.42 on the western flank and around 38.65/38.59 on the eastern flank, revealed the presence of relatively fresh waters in both December and April. In the offshore area of the SA, salinity values ranging between 38.72 and 38.84 were measured during both periods. The greatest salinity values were recorded on the eastern flank: in December at station ESAW-11 (38.95), in the subsurface layer (160-170 m depth), and in April at ESAW-10 (38.94) in the near-surface layer (20-60 m depth, Figure $2 \mathrm{~d}$,e). They were consistent with the inflow of ISW and LIW due to cyclonic NIG circulation. 

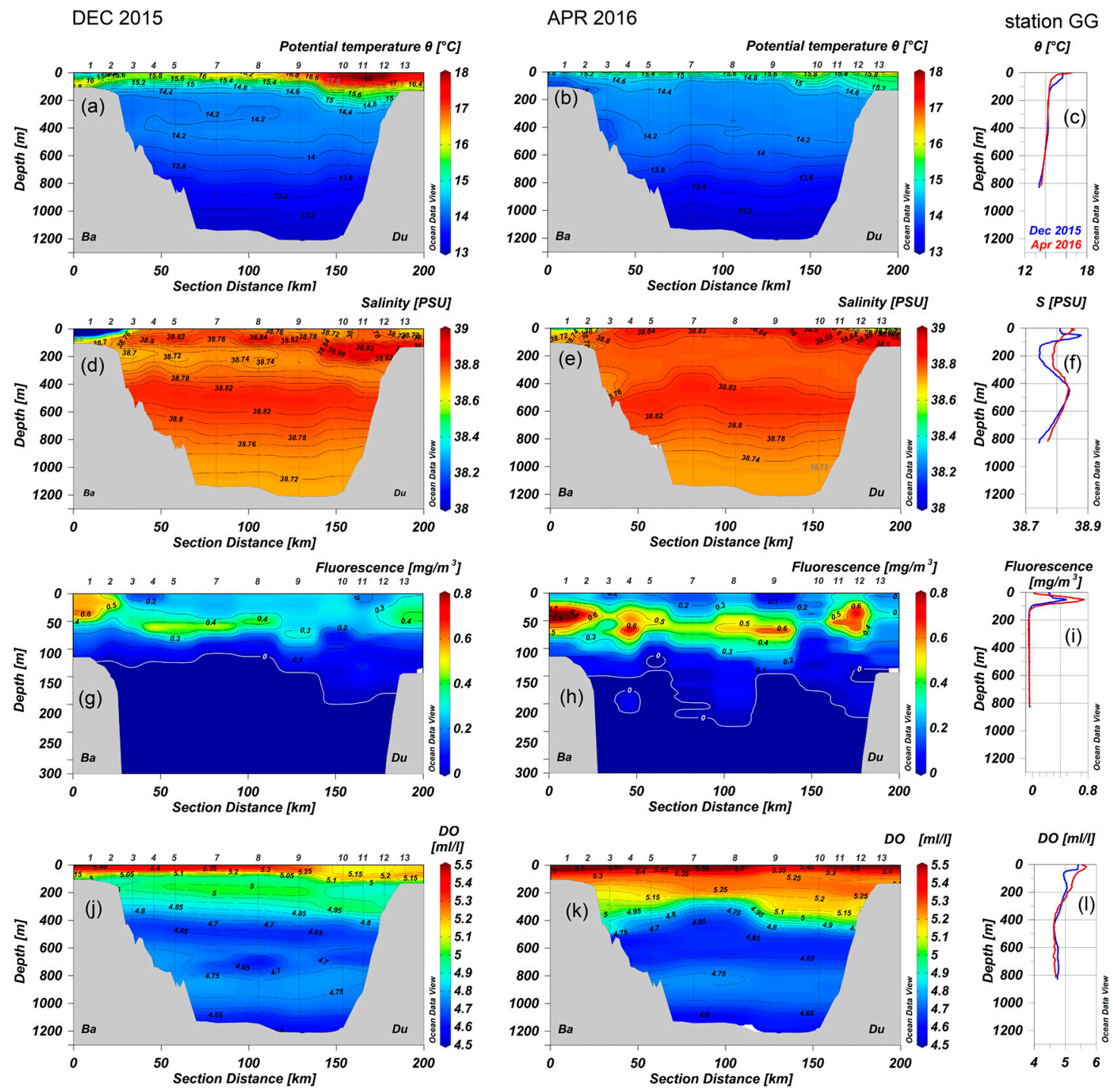

Figure 2. Vertical profiles of potential temperature $(\theta)(\mathbf{a}-\mathbf{c})$, salinity $(S)(\mathbf{d}-\mathbf{f})$, chlorophyll $a$ (by fluorescence) $(\mathbf{g}-\mathbf{i})$ and dissolved oxygen (DO) $(\mathbf{j}-\mathbf{l})$ concentration along the investigated transect in December 2015 and April 2016. For the northernmost station ESAW-GG the corresponding vertical profiles are presented separately.

The vertical distribution of salinity that was observed in December 2015 had a pattern with a double maximum (> 38.80, Figure 2d,f). The first one was roughly located between 50 and $200 \mathrm{~m}$ depth, and the other between 400 and $600 \mathrm{~m}$ depth. At depths between 200 and $400 \mathrm{~m}$, the water was relatively fresh with salinity values around 38.72-38.74. This layer that was occupied by low salinity water was particularly evident in December 2015, when it extended from the western toward the eastern Adriatic shore. This effect was evident near the eastern shore $(<38.75)$ beneath the LIW (characterized by salinity $>38.9$ ), at about $330 \mathrm{~m}$. This layer was at most $200 \mathrm{~m}$ thick within the area that was marked by a salinity value of 38.75 . The structure was patchy rather than uniform, consisting of lenticular-shaped bubbles, showing that it was not horizontally mixed. Within the second salinity maximum layer (between 400 and $600 \mathrm{~m}$ ), peak values of 38.84 were observed. The deepest layers in the SA, about $100 \mathrm{~m}$ thick, had salinity values close to 38.72 . The lowest values were observed on the western shelf (station ESAW-03), at about $190 \mathrm{~m}$ depth $(<38.70)$ and offshore at station ESAW-05, at about $210 \mathrm{~m}$ depth $(<38.71)$. In April 2016, a vertical structure with a double salinity maximum was less evident. The layer of lower salinity (depths $200-400 \mathrm{~m}$ ) was not so fresh. The salinity values were greater than in December (38.78-38.79) and the differences between the eastern and western flanks also 
decreased (Figure 2e). In the deepest layers (below $1000 \mathrm{~m}$ depth), salinity values of 38.73 were greater than in December 2015.

The highest concentrations of the subsurface Chl- $a$ were recorded in December 2015 at the western side, at station ESAW-01 in the layer from 30 to $40 \mathrm{~m}$, ranging between 0.64 and $0.66 \mathrm{mg} \mathrm{m}^{-3}$ (Figure 2g,i). This subsurface maximum diminished toward the centre and toward the eastern side of the SA. There, at the shallow station ESAW-13, the Chl- $a$ maximum was within the range 0.36 to 0.39 $\mathrm{mg} \mathrm{m}^{-3}$. The minimum values were at stations ESAW-12 and distant ESAW-GG. The concentration of Chl- $a$ in April significantly increased (Figure 2h). The maximum values were unevenly distributed, forming distinct subsurface areas. The highest value of $1.14 \mathrm{mg} \mathrm{m}^{-3}$ was again at the western shallow station in the layer $40-50 \mathrm{~m}$. On the eastern side, the maximum was about $0.78 \mathrm{mg} \mathrm{m}^{-3}$. However, a high value of $0.71 \mathrm{mg} \mathrm{m}^{-3}$ was also observed in a thin surface layer of the distant station ESAW-GG (Figure 2i).

In general, the dissolved oxygen (DO) concentrations were characterized by the uppermost surface maximum, and pronounced relative minima between $400 \mathrm{~m}$ and $800 \mathrm{~m}$, and between $1000 \mathrm{~m}$ and the bottom (at the deepest SA stations, Figure 2j). The first of the two mentioned DO minima was found within the salty LIW layer, while the second one indicated the absence of recent ventilation that is usually connected with the sinking of the North Adriatic Dense Water (NAdDW, [40]). The NAdDW is more or less regularly formed over the Northern/Middle Adriatic Shelf during the winter season and, according to its density, sinks to its equilibrium depth in the SA. A layer of slightly greater DO values extended between 800 and $1000 \mathrm{~m}$. It was probably there that the NAdDW, which formed during previous winters, found its equilibrium depth. Another peculiarity is the fact that in April 2016 the DO concentration increased over the entire SA from the surface to $400-450 \mathrm{~m}$ depths along both flanks, and down to $300 \mathrm{~m}$ in the central area (Figure 2k,l). This was a consequence of the winter mixing and a relatively weak vertical convection, which resulted in a more uniform distribution of both temperature and salinity. Along the western flank, in the area of station ESAW-03 we also observed the presence of a fresher and colder vein of water, originating in the Northern/Middle Adriatic, sinking to the western side at about $400 \mathrm{~m}$ depth (Figure 2b,e). Moreover, from the doming of the subsurface isopycnals around station ESAW-07 (not shown here), we might deduce that the pressure gradient between the flanks and the central area of the SA was larger in April than in December. Hence, the quasi-permanent SA cyclonic gyre was probably more active in April than in December, favoring lateral exchanges along the perimeter of the SAP. In concomitance, the exchange between both coastal flanks and the middle of the transect seemed to be less active in April with respect to December 2015.

\subsection{Vertical and Horizontal Distribution of Total Tintinnid Abundance}

In December, the main bulk of the tintinnid population, $62-100 \%$ (the mean $81 \%$ ), was in the upper $100 \mathrm{~m}$ layer along the transect (Figure 3). Tintinnid abundance was, in general, lower at the central deeper stations than at the perimeter stations towards the shoreline. An exceptionally high abundance of tintinnids was found at the westernmost coastal shallow station ESAW-01 with a maximum of 16,640 ind. $\mathrm{m}^{-3}$ in the 50-100 $\mathrm{m}$ layer (Figure 3). The lowest abundance in the upper $100 \mathrm{~m}$ layers was at the central station ESAW-09 (307 and 253 ind. $\mathrm{m}^{-3}$, Figure 3). In the 100-200 m layer, tintinnids occurred in relatively low numbers (104-169 ind. $\mathrm{m}^{-3}$ ). An exception was found at station ESAW-12, with 614 ind. $\mathrm{m}^{-3}$ (Figure 3). However, below $300 \mathrm{~m}$ depth their numbers were uniformly low and usually not exceeding 100 ind. $\mathrm{m}^{-3}$. 


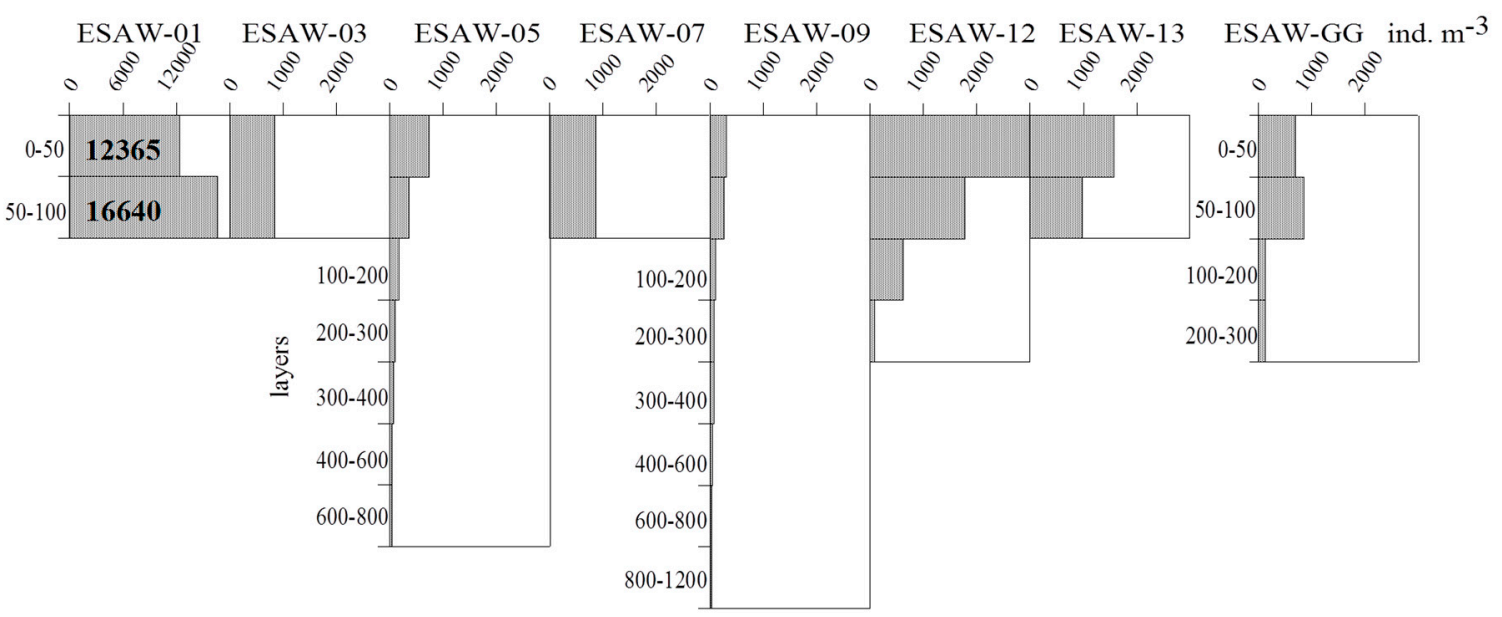

Figure 3. Spatial distribution of the total abundance of tintinnids in December 2015 along the investigated transect and ESAW-GG station.

In April, the tintinnid population was high in the open sea area of the SA and low at the coastal stations (Figure 4).

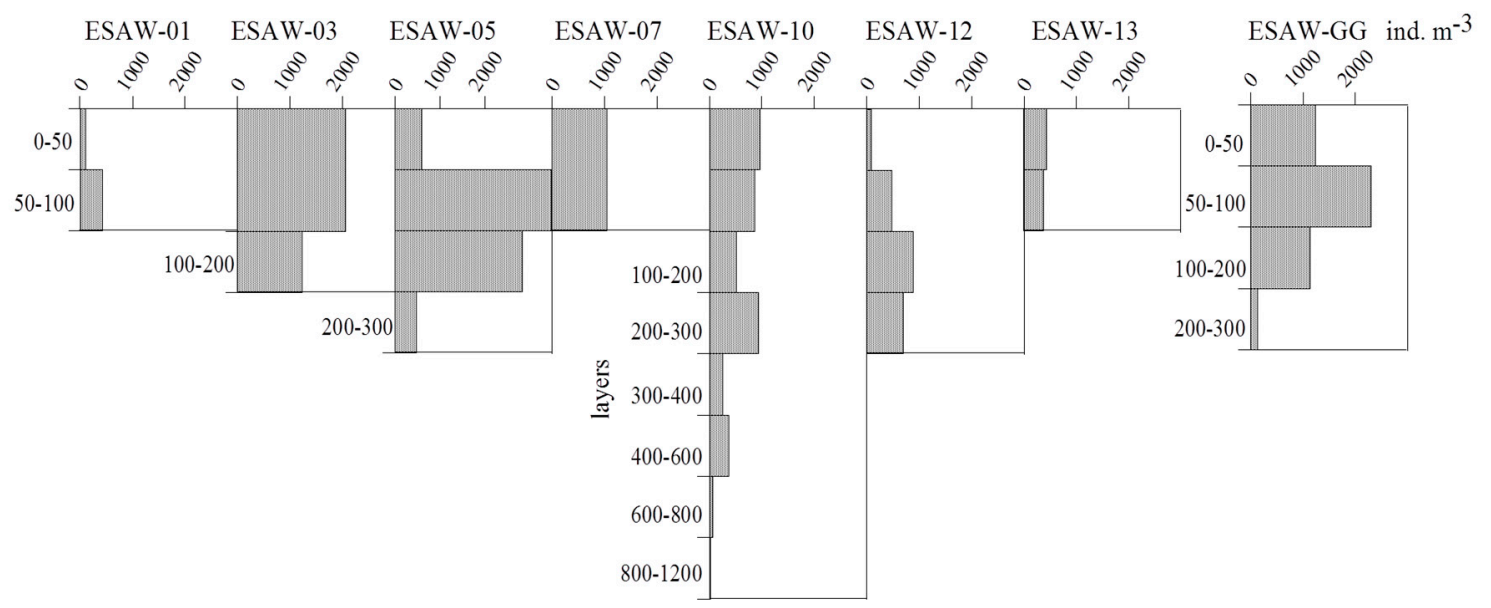

Figure 4. Spatial distribution of the total abundance of tintinnids in April 2016 along the investigated transect and ESAW-GG station.

A shift of tintinnid abundance to the deeper layers was observed (Figure 4). The majority of the population (58-85\%) was located in the layers from 50 to $200 \mathrm{~m}$ depth at the stations ESAW-05, ESAW-12, and ESAW-GG. The greatest abundance ( 3478 ind. $\mathrm{m}^{-3}$ ) was found in the subsurface layer at station ESAW-05 (Figure 4). A marked increase in abundance toward the deeper layers (200-600 m) also occurred at station ESAW-10, where the maximum $\left(930\right.$ ind. $\left.\mathrm{m}^{-3}\right)$ was recorded between 200 and $300 \mathrm{~m}$.

\subsection{Tintinnid Species Composition and Distribution}

Of the total of 63 species, 62 were found in December and 41 in April (Table 2). Only six species were neritic-estuarine (Tintinnopsis radix, Tintinnopsis campanula, Stenosemella nivalis, Stenosemella ventricosa, Helicostomella subulata, and Codonellopsis schabi), while the others were oceanic. Table 2 presents the spatial occurrences of all recorded species. We found 40 surface species (including six neritic-estuarine), 17 subsurface species, five mesopelagic species, and one deep-sea species (Table 2).

In December, the highest species richness (50) was recorded in the surface (49) and subsurface layers (50). Similar species richness was found in the intermediate layers (44), while lower number 
of species (24) occurred in the deeper layers (Table 2). In addition, the greatest species richness was recorded at the two deep open-sea stations, ESAW-05 and ESAW-09 (Table 2). In terms of the species composition near the coast, oceanic tintinnids prevailed at the easternmost station (ESAW-13) whilst the neritic-estuarine species were more numerous at the westernmost station (ESAW-01), as in Table 2.

In contrast to the December period, in April the greatest diversity of species was observed in the intermediate layer (34), Table 2. The highest species richness (32) was registered at the western deepest station, ESAW-05. At the central deep sea stations, ESAW-10 and ESAW-GG species richness was similar, 29 and 27 species, respectively (Table 2). In terms of the species composition near the coast, oceanic tintinnids prevailed at the eastern and western stations, while the neritic-estuarine tintinnids only rarely occurred (Table 2).

Table 2. List of tintinnid taxa identified in the southern Adriatic in December 2015 and April 2016.

\begin{tabular}{|c|c|c|c|c|c|c|c|c|c|c|c|c|c|}
\hline Species & \multicolumn{9}{|c|}{ Station } & \multicolumn{4}{|c|}{ Layers (m) } \\
\hline 1. Codonella amphorella (OSS) & A & A & + & + & $\mathrm{D}$ & A & + & + & + & + & + & + & + \\
\hline 2. Codonella apicata (OS, OSS) & . & . & $\mathrm{D}$ & $\mathrm{D}$ & $\mathrm{D}$ & . & $\mathrm{D}$ & $\mathrm{D}$ & $\mathrm{D}$ & $\mathrm{D}$ & $\mathrm{D}$ & $\mathrm{D}$ & . \\
\hline 3. Codonella aspera (OS, OSS) & + & + & + & A & $\mathrm{D}$ & A & + & + & + & + & + & + & + \\
\hline 4. Codonella galea (OSS) & . & + & + & . & $\mathrm{D}$ & A & + & $\mathrm{D}$ & + & + & + & + & A \\
\hline 7. Tintinnopsis angulata (OS) & . & . & $\mathrm{D}$ & . & $\cdot$ & . & . & $\mathrm{D}$ & . & $\mathrm{D}$ & . & . & $\mathrm{D}$ \\
\hline 8. Tintinnopsis campanula (NE) & $\mathrm{D}$ & . & $\mathrm{D}$ & . & $\mathrm{D}$ & . & $\mathrm{D}$ & + & . & + & $\mathrm{D}$ & $\mathrm{D}$ & $\mathrm{D}$ \\
\hline 9. Tintinnopsis radix (NE) & $\mathrm{D}$ & . & $\mathrm{D}$ & $\mathrm{D}$ & $\mathrm{D}$ & . & $\mathrm{D}$ & $\mathrm{D}$ & . & $\mathrm{D}$ & $\mathrm{D}$ & $\mathrm{D}$ & $\mathrm{D}$ \\
\hline 10. Codonellopsis orthoceras (OS, OSS) & . & . & $\mathrm{D}$ & . & $\mathrm{D}$ & . & . & . & $\mathrm{D}$ & . & . & $\mathrm{D}$ & $\mathrm{D}$ \\
\hline 11. Codonellopsis schabi (NE) & $\mathrm{D}$ & + & + & $\mathrm{D}$ & $\mathrm{D}$ & A & + & + & + & + & + & + & + \\
\hline 15. Cyttarocylis cassis (OSS, OMP) & . & $\mathrm{D}$ & + & . & $\mathrm{D}$ & A & . & $\mathrm{D}$ & A & $\mathrm{D}$ & + & + & $\mathrm{D}$ \\
\hline 16. Cyttarocylis eucecryphalus (OS) & A & A & A & . & . & . & $\mathrm{D}$ & . & A & . & + & A & . \\
\hline 17. Petalotricha ampulla (OSS) & A & + & + & . & . & . & . & . & $\mathrm{D}$ & $\mathrm{D}$ & + & + & . \\
\hline 18. Favella azorica (OS) & . & . & $\mathrm{D}$ & . & . & . & . & $\mathrm{D}$ & $\mathrm{D}$ & $\mathrm{D}$ & $\mathrm{D}$ & $\mathrm{D}$ & . \\
\hline 19. Epiplocylis acuminata (OS) & $\mathrm{D}$ & $\mathrm{D}$ & $\mathrm{D}$ & $\mathrm{D}$ & $\mathrm{D}$ & . & $\mathrm{D}$ & $\mathrm{D}$ & $\mathrm{D}$ & $\mathrm{D}$ & $\mathrm{D}$ & $\mathrm{D}$ & $\mathrm{D}$ \\
\hline 20. Epiplocylis undella (OS) & $\mathrm{D}$ & $\mathrm{D}$ & $\mathrm{D}$ & $\mathrm{D}$ & $\mathrm{D}$ & . & $\mathrm{D}$ & $\mathrm{D}$ & $\mathrm{D}$ & $\mathrm{D}$ & $\mathrm{D}$ & $\mathrm{D}$ & $\mathrm{D}$ \\
\hline 21. Protorhabdonella simplex (OSS) & . & $\mathrm{D}$ & . & . & $\mathrm{D}$ & . & $\mathrm{D}$ & $\mathrm{D}$ & . & $\mathrm{D}$ & $\mathrm{D}$ & . & . \\
\hline 22. Rhabdonella elegans (OS, OSS) & . & . & $\mathrm{D}$ & . & $\mathrm{D}$ & . & . & . & . & $\mathrm{D}$ & . & $\mathrm{D}$ & . \\
\hline 23. Rhabdonella spiralis (OS) & + & $\mathrm{D}$ & + & $\mathrm{D}$ & $\mathrm{D}$ & A & $\mathrm{D}$ & $\mathrm{D}$ & + & $\mathrm{D}$ & + & + & + \\
\hline 24. Parundella aculeata (OS, OSS) & . & . & A & . & . & . & . & $\mathrm{D}$ & . & . & $\mathrm{D}$ & A & . \\
\hline 25. Parundella lohmanni (OMP) & A & + & + & . & $\mathrm{D}$ & A & + & $\mathrm{D}$ & + & $\mathrm{D}$ & + & + & + \\
\hline 33. Amplectella collaria (OSS) & . & . & . & . & $\mathrm{D}$ & . & . & $\mathrm{D}$ & . & $\mathrm{D}$ & $\mathrm{D}$ & . & . \\
\hline 34. Undella biangulata (OS, OSS) & . & . & . & . & $\mathrm{D}$ & A & $\mathrm{D}$ & . & A & . & . & + & + \\
\hline 35. Undella claparedei (OSS) & A & + & + & + & $\mathrm{D}$ & A & + & + & + & + & + & + & + \\
\hline 36. Undella pentagona (OS) & . & . & . & . & $\mathrm{D}$ & . & . & . & . & $\mathrm{D}$ & . & . & . \\
\hline 37. Undella subcaudata acuta (OS) & A & + & + & $\mathrm{D}$ & $\mathrm{D}$ & A & + & + & + & + & + & + & $\mathrm{D}$ \\
\hline 38. Undella subcaudata subcaudata (OSS) & . & . & A & . & $\mathrm{D}$ & A & $\mathrm{D}$ & . & A & + & + & A & . \\
\hline 39. Undella clevei (OS) & . & $\mathrm{D}$ & $\mathrm{D}$ & $\mathrm{D}$ & . & . & $\mathrm{D}$ & . & $\mathrm{D}$ & $\mathrm{D}$ & $\mathrm{D}$ & $\mathrm{D}$ & . \\
\hline 40. Undella hyalina (OS) & . & . & + & . & $\mathrm{D}$ & A & $\mathrm{D}$ & $\mathrm{D}$ & . & + & . & $\mathrm{D}$ & + \\
\hline 41. Undellopsis marsupialis (OSS) & . & A & + & + & $\mathrm{D}$ & A & + & A & A & + & + & + & . \\
\hline 42. Undellopsis subangulata (OS, OSS) & . & . & $\mathrm{D}$ & . & $\mathrm{D}$ & A & $\mathrm{D}$ & . & . & . & A & $\mathrm{D}$ & $\mathrm{D}$ \\
\hline
\end{tabular}


Table 2. Cont.

\begin{tabular}{|c|c|c|c|c|c|c|c|c|c|c|c|c|c|}
\hline Species & \multicolumn{9}{|c|}{ Station } & \multicolumn{4}{|c|}{ Layers (m) } \\
\hline 43. Dictyocysta elegans (OS, OSS) & $\mathrm{D}$ & A & + & . & $\mathrm{D}$ & A & + & A & + & + & + & + & . \\
\hline 45. Dictyocysta lepida (OS, OSS) & $\mathrm{D}$ & + & A & . & . & A & A & . & + & . & $\mathrm{D}$ & + & A \\
\hline 46. Dictyocysta mitra (OS, OSS) & + & + & + & + & $\mathrm{D}$ & A & + & + & + & + & + & + & $\mathrm{D}$ \\
\hline 49. Amphorellopsis acuta (OS) & $\mathrm{D}$ & . & . & . & . & . & . & . & . & $\mathrm{D}$ & $\mathrm{D}$ & . & . \\
\hline 50. Dadayiella ganymedes (OS) & . & $\mathrm{D}$ & + & $\mathrm{D}$ & . & A & A & $\mathrm{D}$ & + & + & + & + & . \\
\hline 51. Dadayiella pachytoecus (OS) & . & . & . & . & $\mathrm{D}$ & . & . & . & . & $\mathrm{D}$ & $\mathrm{D}$ & . & . \\
\hline 52. Steenstrupiella steenstrupii (OS) & + & + & + & + & . & A & + & $\mathrm{D}$ & + & + & + & A & $\mathrm{D}$ \\
\hline 53. Steenstrupiella intumescens (OS, OSS) & . & . & $\mathrm{D}$ & . & . & . & $\mathrm{D}$ & $\mathrm{D}$ & . & $\mathrm{D}$ & . & . & . \\
\hline 58. Eutintinnus fraknoi (OS) & $\mathrm{D}$ & $\mathrm{D}$ & $\mathrm{D}$ & $\mathrm{D}$ & $\mathrm{D}$ & A & $\mathrm{D}$ & + & $\mathrm{D}$ & + & + & + & + \\
\hline 59. Eutintinnus stramentus (OSS) & . & . & $\mathrm{D}$ & . & . & . & $\mathrm{D}$ & $\mathrm{D}$ & $\mathrm{D}$ & $\mathrm{D}$ & $\mathrm{D}$ & . & . \\
\hline 60. Salpingella acuminata (OS) & $\mathrm{D}$ & + & + & + & $\mathrm{D}$ & A & + & + & + & + & + & + & A \\
\hline 61. Salpingella glockentoegeri (OS, OSS) & . & . & A & . & $\mathrm{D}$ & A & . & A & + & $\mathrm{D}$ & + & A & . \\
\hline 62. Salpingella rotundata (OS) & . & . & + & $\mathrm{D}$ & $\mathrm{D}$ & . & $\mathrm{D}$ & . & . & $\mathrm{D}$ & $\mathrm{D}$ & A & . \\
\hline 63. Salpingella subconica (OS) & . & $\mathrm{D}$ & . & . & $\mathrm{D}$ & . & . & $\mathrm{D}$ & . & $\mathrm{D}$ & $\mathrm{D}$ & . & . \\
\hline TOTAL December & 20 & 27 & 40 & 20 & 42 & . & 38 & 34 & 34 & 49 & 50 & 44 & 24 \\
\hline TOTAL April & 14 & 20 & 32 & 8 & . & 29 & 22 & 16 & 27 & 22 & 31 & 34 & 14 \\
\hline
\end{tabular}

" + " indicates presence in both December and April, " $\mathrm{D}$ " indicates presence only in December, while " $\mathrm{A}$ " indicates presence only in April. Roman numerals indicate depth layer $(\mathrm{I}=0-50 \mathrm{~m}, \mathrm{II}=50-100 \mathrm{~m}, \mathrm{III}=100-400 \mathrm{~m}, \mathrm{IV}=$ 400-1200 m). NE = neritic-estuarine species, OS = oceanic surface species, OSS = oceanic subsurface species, OMP = oceanic mesopelagic species, ODS = oceanic deep-sea species.

\subsection{Dominant Species in the Surface and Subsurface Layers $(0-100 \mathrm{~m})$}

The nine dominant species within the surface and subsurface layers in December were Codonellopsis schabi, Salpingella acuminata, Eutintinnus lusus-undae, Undella claparedei, Codonella aspera, Amphorellopsis acuta, Rhabdonella spiralis, Protorhabdonella simplex, and Steenstrupiella steenstrupii. These species accounted for $37-85 \%$ of the total tintinnid abundance (Figure 5A). Neritic species Codonellopsis schabi was markedly predominant at all stations; an exceptionally high value of 13,414 ind. $\mathrm{m}^{-3}(81 \%)$ was found in the subsurface layer at the western coastal station ESAW-01. Along with Codonellopsis schabi, higher abundances were recorded for other neritic-estuarine species Tintinnopsis campanula (1485 ind $\mathrm{m}^{-3}$ ), Tintinnopsis radix (1229 ind $\mathrm{m}^{-3}$ ), and Helicostomella subulata (947 ind. $\mathrm{m}^{-3}$ ). In addition, the contribution of oceanic species Amphorellopsis acuta to total tintinnid abundance was very high (23\%) in the surface layer of this coastal station (Figure $5 \mathrm{~A})$. Toward the open sea, at stations ESAW-03, ESAW-05, and ESAW-07, oceanic species Undella claparedei, Salpingella acuminata, Eutintinnus lusus-undae, Rhabdonella spiralis, and neritic-estuarine species Codonellopsis schabi made up more than $40 \%$ of the total abundance of tintinnids in the surface and subsurface layers (Figure $5 \mathrm{~A}$ ). At the deep open sea station ESAW-09, the contribution of species Undella claparedei to total tintinnid abundance increased, while Rhabdonella spiralis almost disappeared. The contribution of Rhabdonella spiralis to total tintinnid abundance markedly decreased toward the eastern stations while Eutintinnus lusus-undae and Codonellopsis schabi increased (Figure 5A). At the northernmost open sea station ESAW-GG, a contribution of dominant species was similar, as in the open sea stations ESAW-07 and ESAW-09.

In April, the following species dominated in the surface and subsurface layer: Undella claparedei, Codonella aspera, Codonella amphorella, and Steenstrupiella steenstrupii (Figure 5B). Species Undella claparedei was markedly predominant at all stations (except the western coastal ESAW-01) with maximum contribution of $81 \%$ to total tintinnid abundance in the subsurface layer at station ESAW-05 (Figure 5B). Along with this species, Codonella aspera also makes a significant contribution to total tintinnid abundance in the surface layer along the transect (Figure 5B). Different features were observed 
at western coastal station, ESAW-01, where the contribution of Undella claparedei to total tintinnid abundance markedly decreased and Codonellopsis schabi increased (28-33\%). By contrast, at the eastern coastal station, ESAW-13 Codonellopsis schabi was only present in the subsurface layer with a low contribution (Figure 5B).
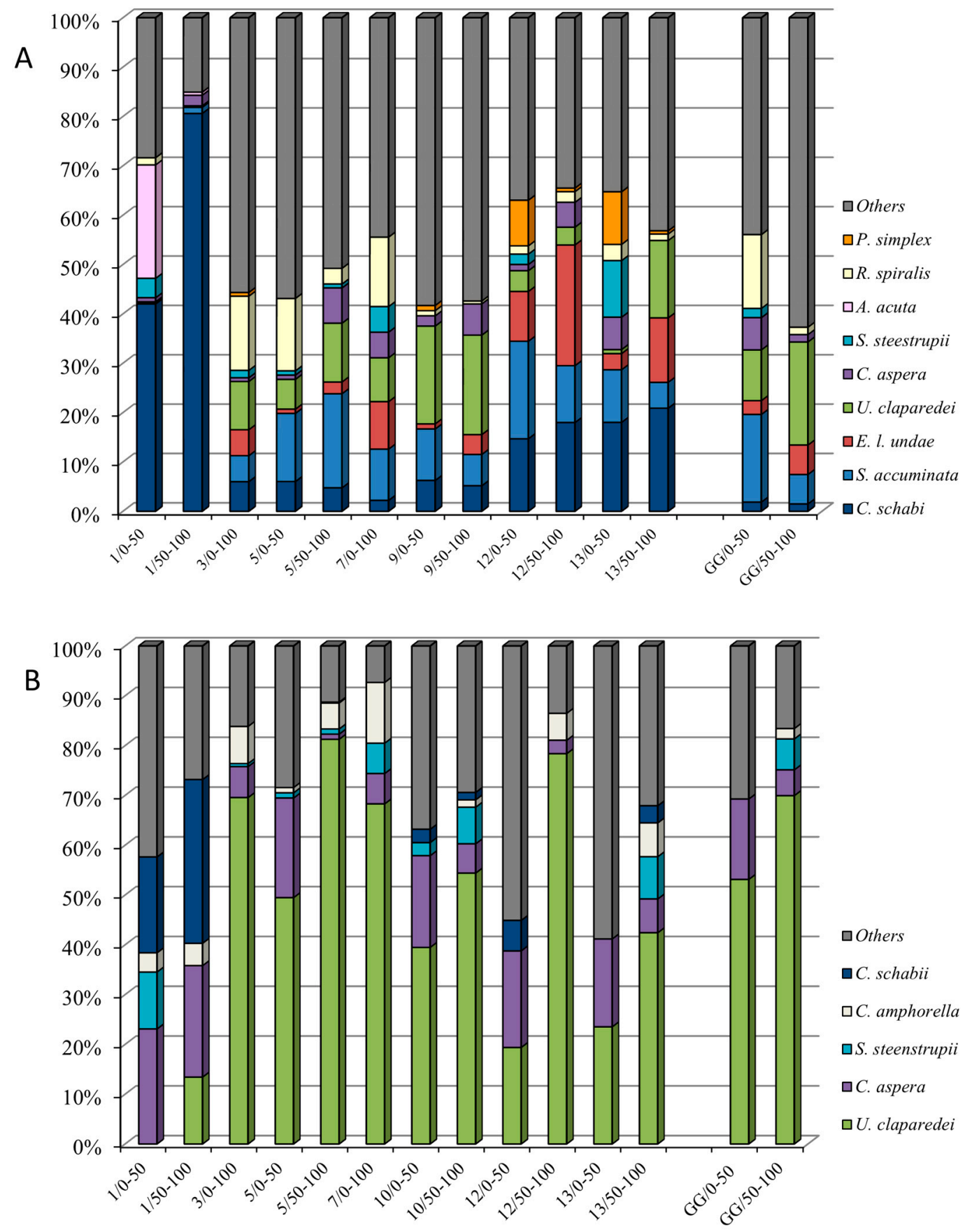

Figure 5. Percentage contributions of the dominant species to total abundance of tintinnids in surface and subsurface layers (0-100 m) in (A) December 2015 and (B) April 2016.

\subsection{Dominant Species in the Mesopelagic Layers (100-300/400 m)}

In December, the dominant species were Codonellopsis schabi, Undella claparedei, Codonella aspera, Epiplocylis undella, and Dictyocysta mitra. These five species accounted for between 50 and $71 \%$ in the intermediate layers (100-400 m) at stations ESAW-05, ESAW-09, ESAW-12, and ESAW-GG. 
Unlike other stations, at ESAW-12, tintinnids reached a high abundance $\left(614 \mathrm{ind} . \mathrm{m}^{-3}\right)$ in the layer 100-200 m. The dominant species was the neritic-estuarine Codonellopsis schabi, making up $46 \%$ of the total tintinnid abundance. In addition, two other neritic-estuarine species, Tintinnopsis radix and Tintinnopsis campanula, were recorded in this layer with contribution of 5 and $6 \%$ in total tintinnid abundance, respectively.

In April, species Undella claparedei accounted for between 35 and $60 \%$ at all stations (Figure 6B). This species was especially abundant in the layer between 100 and $200 \mathrm{~m}$ at ESAW-05 with the highest value of 1453 ind. $\mathrm{m}^{-3}$. Alongside Undella claparedei, the main bulk of the population in the intermediate layers consisted of two other species: Codonella amphorella and Parundella lohmanni $(20-43 \%)$. Although rare, Dictyocysta lepida was found in high abundance (max. 38 ind. $\mathrm{m}^{-3}$ ) in mesopelagic layers at all investigated stations.
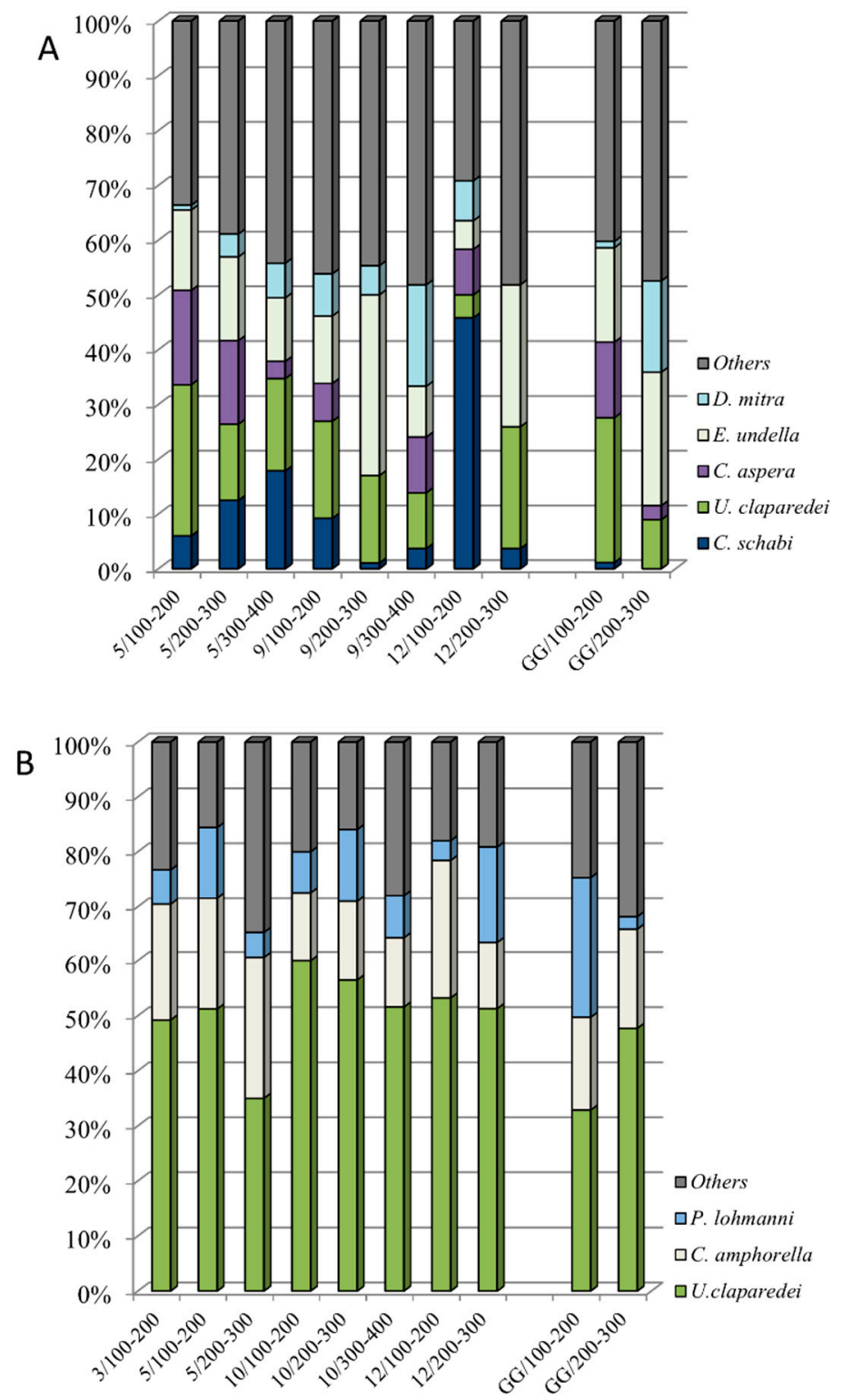

Figure 6. Percentage contribution of the dominant species to the total abundance of tintinnids in the mesopelagic layers (100-300/400 m) in December 2015 (A) and April 2016 (B). 


\subsection{Dominant Species in the Deep Sea Layers (400-1200 m)}

In the deepest part of the SA, tintinnid population was scarce both in number of species and total abundances. December's population was mainly composed of oceanic species Xystonellopsis scyphium, Undella claparedei, Epiplocylis undella, Dictyocysta mitra, and neritic Codonellopsis schabi with 48 and $74 \%$ contribution at stations ESAW-05 and ESAW-09, respectively (Figure 7A).
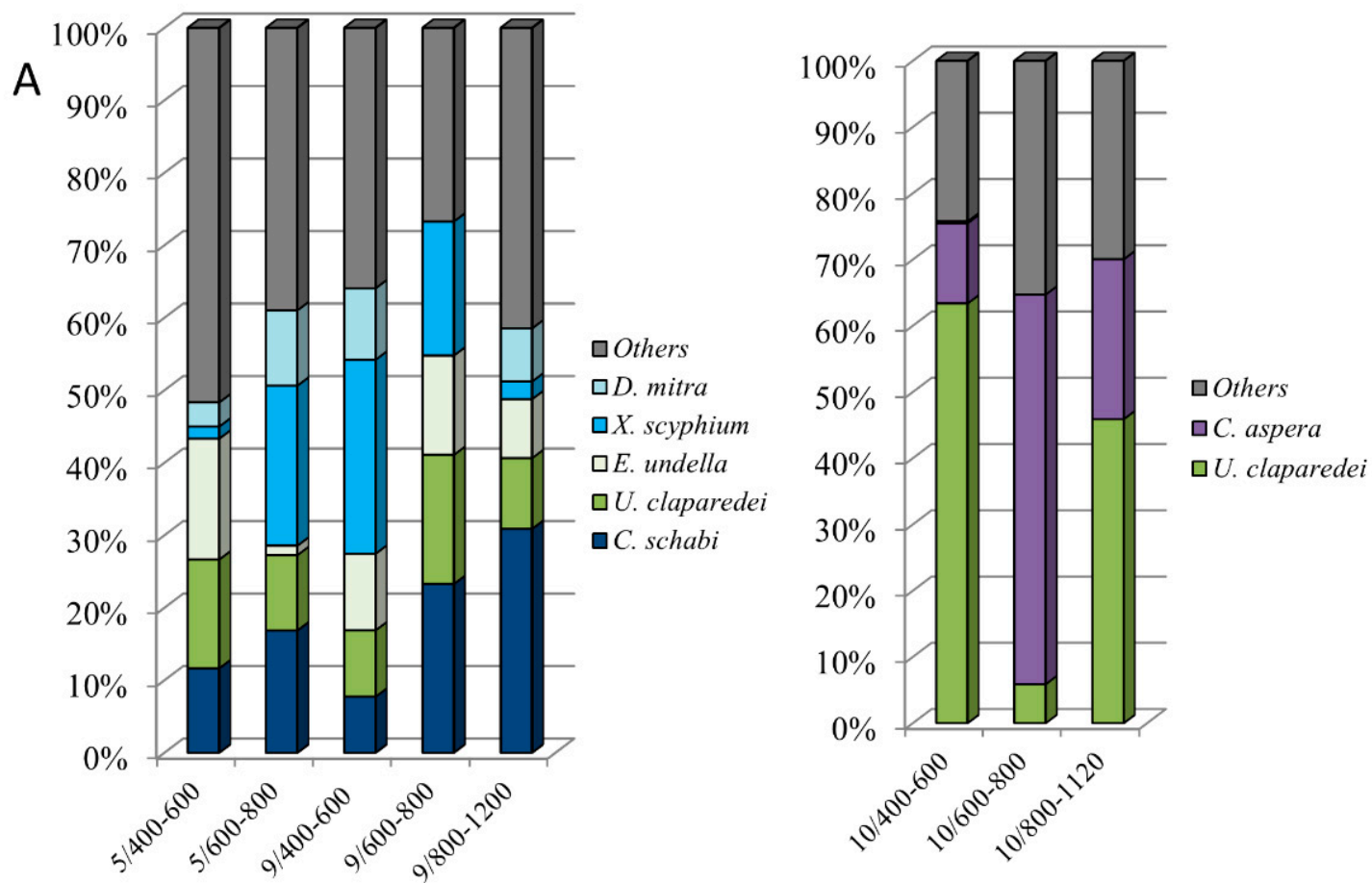

Figure 7. Percentage contribution of dominant species to the total abundance of tintinnids in deep layers (400-1200 m) in December 2015 (A) and April 2016 (B).

In April, Undella claparedei was the dominant species making up 64 and $45 \%$ of the tintinnid population in the 400-600 m and 800-1120 m layers at ESAW 10, respectively. Species Codonella aspera dominated in the $600-800 \mathrm{~m}$ layer with a contribution of $58 \%$ to total tintinnid abundance.

\subsection{Relationship between Dominant Species and Environmental Parameters}

In December 2015, only the abundance of Amphorellopsis acuta was negatively correlated with salinity $(p \leq 0.05)$. The abundance of deep sea species Xystonellopsis scyphium was in negative correlation with temperature $(p \leq 0.05)$, while other dominant species showed positive correlations with temperature ( $p$ in range $0.001-0.05$ ) (Table 3). Most of those dominant species showed a positive correlation ( $p$ in range 0.001-0.01) with Chl- $a$ and DO (Table 3). Only deep sea species Xystonellopsis scyphium was in negative correlation with DO. In April, Codonella aspera and Undella claparedei, which was markedly predominant at all stations, showed a positive correlation $(p \leq 0.05$ and $p \leq 0.01$, respectively) with salinity (Table 3 ). The abundance of epipelagic species Steenstrupiella steenstrupii was positively correlated with temperature $(p \leq 0.01)$, Chl-a $(p \leq 0.001)$, and DO $(p \leq 0.01)$, while the mesopelagic species Parundella lohmani was negatively correlated with these parameters $(p \leq 0.05$, $p \leq 0.001, p \leq 0.05$, respectively). The abundance of Codonella aspera was in positive correlation with salinity and DO $(p \leq 0.05)$. In addition, the abundance of Codonella amphorella was negatively correlated with Chl- $a(p \leq 0.05)$ (Table 3).

The PCA ordination of dominant species of tintinnids in relation to environmental variables was used to search for the main factors that affect their abundances (Figure 8). The first principal component explained $30.6 \%$ of the variance and was closely related to temperature. The second principal 
component explained $19.4 \%$ of the variance and it was closely related with depth and dissolved oxygen. Tintinnid dominant species were distributed in groups, based on the correlation between them. Species Codonellopsis schabi, Amphorellopsis acuta, Rhabdonella spiralis, Dictyocysta mitra, Protorhabdonella simplex, and Eutintinnus lusus-undae were closely related to the temperature, while Steenstrupiella steenstrupii, Salpingella acuminata, and Codonella aspera correlated well with oxygen. Positive relationships with depth and negative with dissolved oxygen were shown for Xystonellopsis scyphium.

Table 3. Correlations between dominant tintinnid species, temperature (Temp), salinity (Sal), chlorophyll- $a$ (Chl- $a)$, and DO (dissolved oxygen).

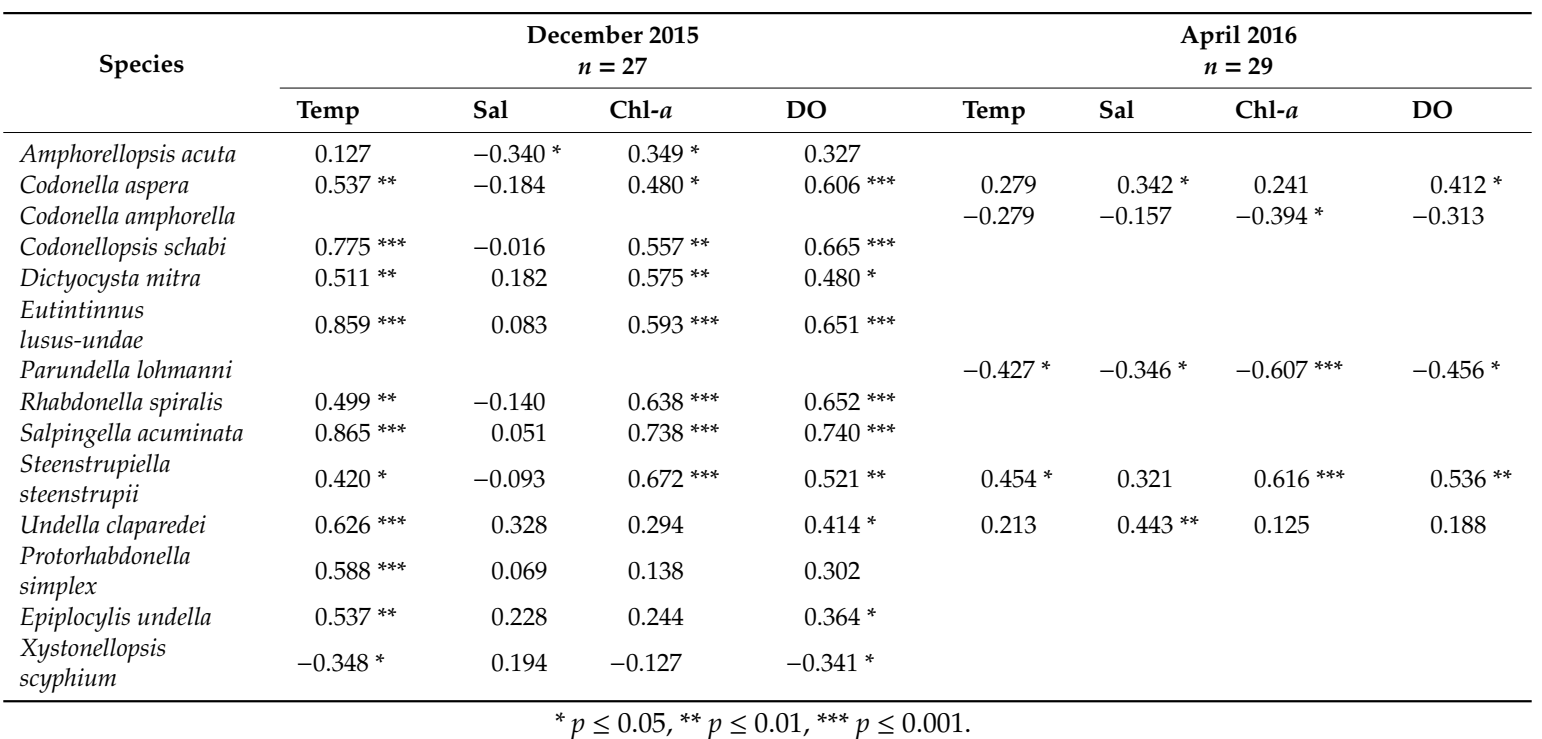

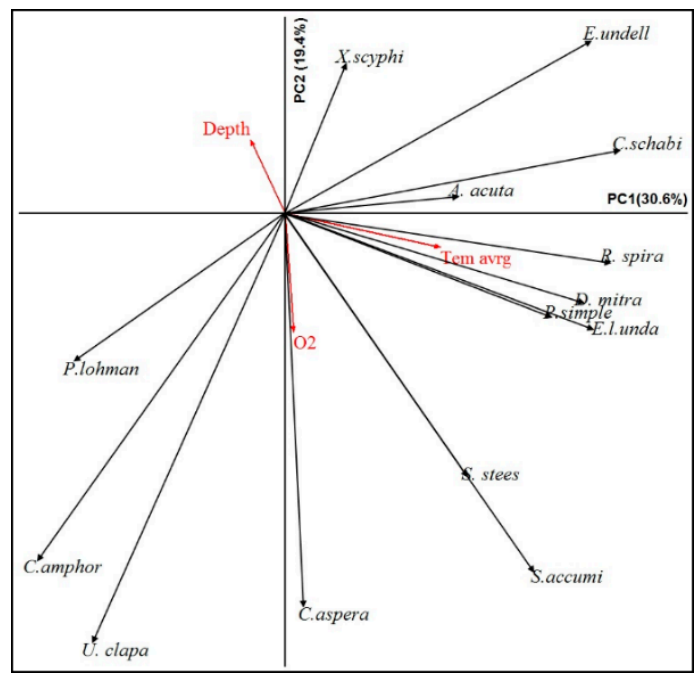

Figure 8. Principal component analysis (PCA) of tintinnid ciliate species abundance and environmental variables. The $x$-axis is the first PCA axis, and the $y$-axis is the second PCA axis. Environmental variables (Temeperature-Temp, Salinity-Sal, Oxygen- $\mathrm{O}_{2}$ and Depth) and tintinnid species are indicated by red and black arrows, respectively. Abbreviation of analysed tintinnid species: C.schabi-Codonellopsis schabi, A.acuta-Amphorelopsis acuta, R.spira-Rhabdonella spiralis, P.simple-Protorhabdonella simplex, D.mitra-Dictyocysta mitra, E.l.unda-Eutintinnus lusus-undae, S.stees-Steenstrupiella steenstrupii, S.accumi-Salpingella acuminata, P.lohman—Parundella lohmanni, C.amphor-Codonella amphorella, U.clapa-Undella claparedei, C.aspera-Codonella aspera, E.undell-Epiplocylis undella, X.scyphi-Xystonellopsis scyphium. 


\section{Discussion}

The high diversity of species and low abundances at the central stations of the SA, as well as high abundance at the perimeter stations towards the shoreline observed in December 2015, are a typical feature of the Adriatic Sea for winter and early spring that is already documented in many studies while using the same sampling methods [11-14,31,34]. The observed abundance distribution was positively correlated with the temperature and Chl- $a$. A similar distribution was recorded in other regions of the Mediterranean Sea, even when different sampling methods were used [41,42].

In December 2015 resident oceanic species in the SA, Salpingella acuminata, Undella claparedei, Eutintinnus lusus-undae, Rhabdonella spiralis, and neritic-estuarine species Codonellopsis schabi dominated at most stations. At the eastern stations, the very rare oceanic species with sporadic occurrence, Protorhabdonella simplex [39] was recorded in considerable abundance in the surface layer. In the eastern part of the SA, we also recorded species Eutintinnus elegans, Eutintinnus latus, Steenstrupiella intumescens, Undella subcaudata acuta, and Undella biangulata, which are known immigrants from either the Eastern Mediterranean or the Ionian Sea and could act as indicators of the advection of water masses from external basins [13,43]. The remarkable presence of LIW (salinity > 38.9) was evident in December as well as in April. In general, the eastern part of the SA was under the influence of the inflow of Ionian Surface water (ISW) in the upper layer and of Levantine Intermediate Water (LIW) in the intermediate layer. The volume of this flow is greater in late autumn and winter [24,25]. According to Kršinić and Grbec [13], LIW is of particular importance in the transport of oceanic tintinnid species from the Eastern Mediterranean into the SA [13]. In December, at the western part of the SA, tintinnids reached notably high abundance at coastal station ESAW-01, with a maximum of 16,640 ind. $\mathrm{m}^{-3}$ in the subsurface layer with Codonellopsis schabi as a dominant species that accounted for the $81 \%$ of total tintinnid abundance. This high abundance was accompanied by low chlorophyll- $a$ values, which were probably due to tintinnid grazing activity. This population density is one of the highest ever recorded for tintinnid communities in the SA. Kršinić [43] registered a high density of tintinnids near the western Adriatic coast (at a coastal station close to Bari) in November 1989, but those values were several times lower than ours. Besides Codonellopsis schabi, as a dominant species at ESAW-01, species composition mainly consisted of the neritic-estuarine species, such as Tintinnopsis campanula, Tintinnopsis radix, and Helicostomella subulata, which revealed a significant influence of the relatively fresh eutrophic highly productive waters from the northern Adriatic that are usually advected by the WAC [39]. Another specific feature is that a rather uncommon surface oceanic species Amphorellopsis acuta occurred in markedly high numbers at ESAW-01. Although, rare in the open SA, this oceanic species can be found in the western part of the northern Adriatic, where it usually achieves its highest abundance in September [39]. Therefore it is likely that this species was also transported by the southward flow of eutrophic less saline waters by WAC. Western coastal stations were generally characterized by high Chl- $a$ concentration in the surface layer, which is likely responsible for the increased abundance of Amphorellopsis acuta as well as tintinnids in general.

Apart from the extremely high abundant neritic-estuarine species Codonellopsis schabi at the western coastal station (ESAW-1), an unusual feature in its horizontal spreading towards the eastern coast and towards greater depths was recorded in December 2015. Codonellopsis schabi has so far only been found near the coasts, in the channels and estuaries, while it has been found very sporadically at the surface of the open SA [43]. This was in accordance with the specific water mass distributions in the years of 2015 and 2016 in the SA. In this regard, an unusual feature with double salinity maximum layers ( 50-100/200 $\mathrm{m}$ and $\sim 400-600 \mathrm{~m}$ ) with a relative salinity minimum layer in between them was found in December 2015. The layer that was occupied by low salinity water extended from the western towards the eastern Adriatic shore and it was characterized by relatively high abundance and contribution of neritic-estuarine species Codonellopsis schabi, Tintinnopsis radix, and Tintinnopsis campanula in the tintinnid population. DO concentrations within the salinity minimum layer were high, which implies that recent ventilation had occurred. Most of the dominant species in this layer, as well as in surface and subsurface layers, had a positive correlation with DO in December. Only 
the deep sea species Xystonellopsis scyphium was negatively correlated with DO. Kokkini et al. [44] observed such a double salinity maximum structure in summer 2015, which lasted until the end of 2016. In 2012, abundant and exceptionally dense water $\left(\sigma \theta>30 \mathrm{~kg} \mathrm{~m}^{-3}\right)$ was formed and advected from the north and middle Adriatic toward the SAP after a harsh winter (see e.g., $[45,46]$ ). In the period 2013-2015, winter convection was weak [44]. Thus, we can hypothesize that relatively fresh and cold waters advected from the northern Adriatic to the SA, found their equilibrium depths within the layer 100-400 m occupied by the LIW, so the LIW was pushed deeper (400-600 m). LIW indicator species, as recognized by Kršinić [43], such as Eutintinnus latus, Undella subcaudata acuta, and Undella biangulata, were registered in this deeper layer $(400-600 \mathrm{~m})$ in December. Kokkini et al. [44] state that the large fresh water discharge in the northern Adriatic (corroborated by the Po river discharge in 2014 being greater by about $50 \%$ than the average yearly values) is the origin of these relatively fresh waters that spread toward the south. This fresh water spreads toward the open sea, and further toward the eastern coast, being embedded in either the cyclonic sub-basin circulation in the SA, or in the mesoscale eddies. Contemporarily, along the eastern shore there was an enhanced inflow of salty surface Ionian and Levantine waters from the adjacent Ionian Sea both in 2015 and 2016, favoured by the cyclonic mode of the North Ionian Gyre [47]. These salty veins partly deviated toward the open sea and toward the western shore transported by the quasi-permanent cyclonic SA gyre. Hence, due to the local cyclonic circulation and to the strong mesoscale activities, both layers, the saltier one (from the east) and fresher one (from the west flank), were able to spread toward the open sea. This interaction of different water transport systems is probably the reason for coastal species as well as oceanic species being found in both the open sea and in the coastal area. The population shift of some of the most abundant subsurface oceanic species in the SA, such as Undella claparedei [43], toward the surface layer in December 2015, could be in connection with the described specific position of different water masses. This species was generally found in lower abundances in comparison to a previous research (see [43]).

In April 2016, species diversity decreased when compared to the December 2015 survey. The horizontal distribution was characterized by a core of pronounced abundance in the central area of the SA, extending westward. In particular, this tintinnid distribution was in accordance with the salinity distribution, which is confirmed by the correlation between these parameters. Turbulent mixing at shelf-break frontal zones, between less dense coastal water and denser open sea water, and/or eddy instability, are mechanisms that can drive upper-layer mixing, stimulating primary production [48], and hence the increased abundance of tintinnids at the mid-shelf station ESAW-03. Winter mixing was responsible for nutrient enrichment of the euphotic layer and the phytoplankton development, which in turn created conditions for the higher abundance of tintinnids at the western deep sea station (ESAW-05) in April 2016. Vertical convection and mixing occurred during winter 2016 down to nearly $400 \mathrm{~m}$ depth due to severe winter conditions [44]. The vertical distribution profile of nitrate in the open SA [49] showed that the nitrate was depleted in the upper layer, probably due to phytoplankton activity. In April 2016, the main bulk of the population was situated in the subsurface layer, which corresponded to a higher concentration of Chl- $a$. However, a shift of tintinnid abundance to the deeper layers was observed. Generally, the surface layers had a lower abundance in April and the majority of tintinnid populations consisted of Codonella aspera and Steenstrupiella steenstrupii. The most important contributor to the subsurface community was Undella claparedei, which prevailed in every layer at all stations in April 2016, which is in accordance with previous research [12,14]. Unusually high abundances of tintinnids and the greatest species richness were registered from 100 to $300 \mathrm{~m}$ depth, which could be a consequence of the winter vertical mixing that brings tintinnids and their food (phytoplankton) to the deeper layers. The community was characterized by the presence of surface and subsurface oceanic tintinnid species in April in the deep layers, which indicated that they can survive for more than a month in the deep, since vertical mixing at the open sea usually ceases by the end of February and beginning of March [28,33]. The greater part of the mesopelagic population was made up of subsurface oceanic species Undella claparedei and Codonella amphorella, especially in the layer from 100 to $300 \mathrm{~m}$. This is in accordance with the vertical distribution of tintinnids in the open southern Adriatic 
during the winter convection events of 2008 [43] and 2015 [34]. Our data are comparable with those that were recorded in April 1986 in the open SA when some similar hydrographic/hydrological and biological characteristics were recorded: strong LIW inflow, downward transport, and phytoplankton bloom [12,50].

In April, a markedly high abundance of mesopelagic species Parundella lohmanni was registered between $100 \mathrm{~m}$ and $400 \mathrm{~m}$ depth at the central SA stations, as well as at the ESAW-GG station, which can be related to the northward advection of LIW towards the Middle Adriatic. In the deep layers of the SA the species Undella claparedei, Codonella aspera, and Codonella amphorella were highly abundant, as also observed in the mesopelagic and subsurface layers. In addition, scarce subsurface species Dictyocysta lepida [39] was found in a relatively high abundance in the mesopelagic layer.

The characteristic species and their spatial and temporal distribution found in this research are not completely in accordance with previous studies while using the same sampling methods [12-14,51]. These variations are probably caused by an unusual distribution of water masses in the SA in the years 2015 and 2016. Additionally, seasonal changes in the water column structure, in particular due to the winter vertical mixing, which happens in specific hydro-meteorological conditions with different strength in different years, as well as the ingression of different water masses into the Adriatic, can cause marked shifts in the occurrence and abundance of tintinnids in post winter periods.

\section{Conclusions}

During both investigated periods physical forces (winter vertical convection, lateral exchanges between coastal and the open sea waters, and ingression of water masses of different properties) created environmental conditions that were of crucial significance for the spatial and temporal distribution of tintinnid ciliates in the southern Adriatic. Two different types of tintinnid horizontal distribution could be defined in the two investigated periods. The horizontal distribution of tintinnids in December showed lower abundance at the central stations of the SA and higher abundance at the perimeter stations towards the coast. Vertical species distribution was shaped by a double salinity maximum, while strong LIW ingression influenced the species composition in the SA. In April 2016, the tintinnid horizontal distribution was characterized by a high abundance in the central area of the SA with decreasing abundance toward the coast, which is probably a consequence of late-winter/early-spring blooms near the centre of the SAP. A shift of abundance toward the deeper layers in April is probably caused by convection-driven sinking of tintinnids as well as phytoplankton, which enriched the deep sea communities with surface and subsurface species. It is likely that surface species can survive and contribute to deep sea fauna for a substantial amount of time. Further studies that are based on long term surveys will be important in confirming the recurrent nature of tintinnid distribution under the influence of winter physical forcings as well as different circulation patterns in the Adriatic Sea.

Author Contributions: Microzooplankton Analysis and Writing (Original Draft Preparation), J.N.; WritingReview and Editing, M.B. (Mirna Batistić); Zooplankton Sampling and Paper Editing, R.G.; Physical Oceanography Data (Writing and Contribution to Discussion), V.K. and M.B. (Manuel Bensi).

Funding: This study was carried out within the framework of the EUROFLEETS2 research infrastructures project under the 7th Framework Programme of the European Commission (grant agreement 312762). The research was also funded by the Italian national project RITMARE (Ricerca Italiana per il Mare, grant numbers: SP3-WP3-AZ1; SP4-LI4-WP1; SP5-WP3-AZ3) and the Croatian Science Foundation, under project IP-2014-09-2945.

Acknowledgments: We thank to anonymous reviewers for constructive comments and valuable suggestions. We also thank the captain and the crew of R/V Bios dva and all the scientific and technical staff who took part in the cruises for their professionalism.

Conflicts of Interest: The authors declare no conflict of interest.

\section{References}

1. Pierce, R.W.; Turner, J.T. Ecology of planktonic ciliates in marine food webs. Rev. Aquat. Sci. 1992, 6, $139-181$. 
2. Pierce, R.; Turner, J. Global biogeography of marine tintinnids. Mar. Ecol. Prog. Ser. 1993, 94, 11-26. [CrossRef]

3. Rassoulzadegan, F.; Laval-Peuto, M.; Sheldon, R.W. Partitioning of the food ration of marine ciliates between pico- and nanoplankton. Hydrobiologia 1988, 159, 75-88. [CrossRef]

4. Bernard, C.; Rassoulzadegan, F. The role of picoplankton (cyanobacteria and plastidic picoflagellates) in the diet of tintinnids. J. Plankton Res. 1993, 15, 361-373. [CrossRef]

5. Stoecker, D.K.; Sanders, N.K. Differential grazing by Acartia tonsa on a dinoflagellate and a tintinnid. J. Plankton Res. 1985, 7, 85-100. [CrossRef]

6. Sherr, E.B.; Sherr, B.F.; Fallon, R.D.; Newell, S.Y. Small, aloricate ciliates as a major component of the marine heterotrophic nanoplankton. Limnol. Oceanogr. 1986, 31, 177-183. [CrossRef]

7. Paffenhöfer, G.-A. On the relation of structure, perception and activity in marine planktonic copepods. J. Mar. Syst. 1998, 15, 457-473. [CrossRef]

8. Thompson, G.A.; Alder, V.A.; Boltovskoy, D.; Brandini, F. Abundance and biogeography of tintinnids (Ciliophora) and associated microzooplankton in the Southwestern Atlantic Ocean. J. Plankton Res. 1999, 21, 1265-1298. [CrossRef]

9. Dolan, J.R. Tintinnid ciliate diversity in the Mediterranean Sea: Longitudinal patterns related to water column structure in late spring-early summer. Aquat. Microb. Ecol. 2000, 22, 69-78. [CrossRef]

10. Kršinić, F. Summer distributions of Tintinnids in open waters of the Adriatic Sea. Rapp. Procès-Verbaux La Réun. Comm. Int. Pour Explor. Sci. Mer Mediterr. 1979, 25/26, 107-108.

11. Kršinić, F. On vertical distribution of tintinnines (Ciliata, Oligotrichida, Tintinnina) in the open waters of the South Adriatic. Mar. Biol. 1982, 68, 83-90. [CrossRef]

12. Kršinić, F. Vertical distribution of protozoan and microcopepod communities in the South Adriatic Pit. J. Plankton Res. 1998, 20, 1033-1060. [CrossRef]

13. Kršinić, F.; Grbec, B. Some distributional characteristics of small zooplankton at two stations in the Otranto Strait (Eastern Mediterranean). Hydrobiologia 2002, 482, 119-136. [CrossRef]

14. Kršinić, F.; Grbec, B. Horizontal distribution of tintinnids in the open waters of the South Adriatic (Eastern Mediterranean). Sci. Mar. 2006, 70, 77-88. [CrossRef]

15. Dolan, J.R.; Claustre, H.; Carlotti, F.; Plounevez, S.; Moutin, T. Microzooplankton diversity: Relationships of tintinnid ciliates with resources, competitors and predators from the Atlantic Coast of Morocco to the Eastern Mediterranean. Deep Sea Res. Part I: Oceanogr. Res. Pap. 2002, 49, 1217-1232. [CrossRef]

16. Dolan, J.R.; Ciobanu, M.; Marro, S.; Coppola, L. An exploratory study of heterotrophic protists of the mesopelagic Mediterranean Sea. ICES J. Mar. Sci. 2019, 76, 616-625. [CrossRef]

17. Manca, B.B.; Kovačević, V.; Gačić, M.; Viezzoli, D. Dense water formation in the Southern Adriatic Sea and spreading into the Ionian Sea in the period 1997-1999. MATER MAss Transf. Ecosyst. Response 2002, 33-34, 133-154. [CrossRef]

18. Williams, R.G.; Follows, M.J. The Ekman transfer of nutrients and maintenance of new production over the North Atlantic. Deep Sea Res. Part Oceanogr. Res. Pap. 1998, 45, 461-489. [CrossRef]

19. Marra, J.; Houghton, R.W.; Garside, C. Phytoplankton growth at the shelf-break front in the Middle Atlantic Bight. J. Mar. Res. 1990, 48, 851-868. [CrossRef]

20. Civitarese, G.; Gačić, M. Had the Eastern Mediterranean Transient an impact on the new production in the southern Adriatic? Geophys. Res. Lett. 2001, 28, 1627-1630. [CrossRef]

21. Gačić, M.; Civitarese, G.; Miserocchi, S.; Cardin, V.; Crise, A.; Mauri, E. The open-ocean convection in the Southern Adriatic: A controlling mechanism of the spring phytoplankton bloom. Cont. Shelf Res. 2002, 22, 1897-1908. [CrossRef]

22. Bernardi Aubry, F.; Falcieri, F.M.; Chiggiato, J.; Boldrin, A.; Luna, G.M.; Finotto, S.; Camatti, E.; Acri, F.; Sclavo, M.; Carniel, S.; et al. Massive shelf dense water flow influences plankton community structure and particle transport over long distance. Sci. Rep. 2018, 8, 4554. [CrossRef]

23. Zore, M. On the gradient currents in the Adriatic Sea. Acta Adriat. 1956, 8, 1-38.

24. Grbec, B.; Dulčić, J.; Morović, M. Long-Term changes in landings of small pelagic fish in the eastern Adriatic-Possible influence of climate oscillations over the Northern Hemisphere. Clim. Res. 2002, 20, 241-252. 
25. Gačić, M.; Marullo, S.; Santoleri, R.; Bergamasco, A. Analysis of the seasonal and interannual variability of the sea surface temperature field in the Adriatic Sea from AVHRR data (1984-1992). J. Geophys. Res. Oceans 1997, 102, 22937-22946. [CrossRef]

26. Hopkins, T.; Artegiani, A.; Kinder, C.; Pariante, R. A discussion of the northern Adriatic circulation and flushing as determined from the ELNA hydrography. In The Adriatic Sea, Ecosystem Research Report; Hopkins, T.S., Artegiani, A., Cauwet, G., Degobbis, D., Malej, A., Eds.; European Commission: Brussels, Belgium, 1999; Volume 32, pp. 85-106.

27. Civitarese, G.; Gačić, M.; Lipizer, M.; Eusebi Borzelli, G.L. On the impact of the Bimodal Oscillating System (BiOS) on the biogeochemistry and biology of the Adriatic and Ionian Seas (Eastern Mediterranean). Biogeosciences 2010, 7, 3987-3997. [CrossRef]

28. Batistić, M.; Viličić, D.; Kovačević, V.; Jasprica, N.; Garić, R.; Lavigne, H.; Carić, M. Occurrence of winter phytoplankton bloom in the open southern Adriatic: Relationship with hydroclimatic events in the Eastern Mediterranean. Cont. Shelf Res. 2019, 174, 12-25. [CrossRef]

29. Gačić, M.; Borzelli, G.L.E.; Civitarese, G.; Cardin, V.; Yari, S. Can internal processes sustain reversals of the ocean upper circulation? The Ionian Sea example. Geophys. Res. Lett. 2010, 37. [CrossRef]

30. Vilibić, I.; Matijević, S.; Šepić, J.; Kušpilić, G. Changes in the Adriatic oceanographic properties induced by the Eastern Mediterranean Transient. Biogeosciences 2012, 9, 2085-2097. [CrossRef]

31. Batistić, M.; Jasprica, N.; Carić, M.; Čalić, M.; Kovačević, V.; Garić, R.; Njire, J.; Mikuš, J.; Bobanović-Ćolić, S. Biological evidence of a winter convection event in the South Adriatic: A phytoplankton maximum in the aphotic zone. South. Adriat. Oceanogr. 2012, 44, 57-71. [CrossRef]

32. Batistić, M.; Garić, R.; Molinero, J.C. Interannual variations in Adriatic Sea zooplankton mirror shifts in circulation regimes in the Ionian Sea. Clim. Res. 2014, 61, 231-240. [CrossRef]

33. Ljubimir, S.; Jasprica, N.; Čalić, M.; Hrustić, E.; Dupčić Radić, I.; Car, A.; Batistić, M. Interannual (2009-2013) variability of winter-spring phytoplankton in the open South Adriatic Sea: Effects of deep convection and lateral advection. Cont. Shelf Res. 2017, 143, 311-321. [CrossRef]

34. Lučić, D.; Ljubešić, Z.; Babić, I.; Bosak, S.; Cetinić, I.; Vilibić, I.; Mihanović, H.; Hure, M.; Njire, J.; Lučić, P.; et al. Unusual winter zooplankton bloom in the open southern Adriatic Sea. Turk. J. Zool. 2017, 41, 1024-1035. [CrossRef]

35. Čalić, M.; Ljubimir, S.; Bosak, S.; Car, A. First records of two planktonic Indo-Pacific diatoms: Chaetoceros bacteriastroides and C. pseudosymmetricus in the Adriatic Sea. Oceanologia 2018, 60, 101-105. [CrossRef]

36. Hure, M.; Mihanović, H.; Lučić, D.; Ljubešić, Z.; Kružić, P. Mesozooplankton spatial distribution and community structure in the South Adriatic Sea during two winters (2015, 2016). Mar. Ecol. 2018, 39, e12488. [CrossRef]

37. Kršinić, F. A new type of zooplankton sampler. J. Plankton Res. 1990, 12, 337-343. [CrossRef]

38. Lynn, D. The Ciliated Protozoa. Characterization, Classification and Guide to the Literature, 3rd ed.; Springer Netherlands: Dordrecht, The Netherlands, 2008.

39. Kršinić, F. Tintinnids (Tintinnida, Choreotrichia, Ciliata) in the Adriatic Sea, Mediterranean. Part, I. Taxonomy; Institute of Oceanography and Fisheries: Split, Croatia, 2010.

40. Vilibić, I.; Orlić, M. Adriatic water masses, their rates of formation and transport through the Otranto Strait. Deep Sea Res. Part Oceanogr. Res. Pap. 2002, 49, 1321-1340. [CrossRef]

41. Abbound-Abi Saab, M. Distribution and ecology of tintinnids in the plankton of Lebanese coastal waters (eastern Mediterranean). J. Plankton Res. 1989, 11, 203-222. [CrossRef]

42. Sitran, R.; Bergamasco, A.; Decembrini, F.; Guglielmo, L. Microzooplankton (tintinnid ciliates) diversity: Coastal community structure and driving mechanisms in the southern Tyrrhenian Sea (Western Mediterranean). J. Plankton Res. 2008, 31, 153-170. [CrossRef]

43. Kršinić, F. Tintinnids (Tintinnida, Choreotrichia, Ciliata) in the Adriatic Sea, Mediterranean. Part II. Ecology; Institute of Oceanography and Fisheries: Split, Croatia, 2010.

44. Kokkini, Z.; Mauri, E.; Gerin, R.; Poulain, P.M.; Simoncelli, S.; Notarstefano, G. On the salinity structure in the South Adriatic as derived from float and glider observations in 2013-2016. Deep Sea Res. Part II Top. Stud. Oceanogr. 2019, in press. [CrossRef]

45. Mihanović, H.; Vilibić, I.; Carniel, S.; Tudor, M.; Russo, A.; Bergamasco, A.; Bubić, N.; Ljubešić, Z.; Viličić, D.; Boldrin, A.; et al. Exceptional dense water formation on the Adriatic shelf in the winter of 2012. Ocean Sci. 2013, 9, 561-572. [CrossRef] 
46. Bensi, M.; Cardin, V.; Rubino, A.; Notarstefano, G.; Poulain, P.M. Effects of winter convection on the deep layer of the Southern Adriatic Sea in 2012. J. Geophys. Res. Oceans 2013, 118, 6064-6075. [CrossRef]

47. Gačić, M.; Civitarese, G.; Eusebi Borzelli, G.L.; Kovačević, V.; Poulain, P.-M.; Theocharis, A.; Menna, M.; Catucci, A.; Zarokanellos, N. On the relationship between the decadal oscillations of the northern Ionian Sea and the salinity distributions in the eastern Mediterranean. J. Geophys. Res. Oceans 2011, 116, C12002. [CrossRef]

48. Mann, K.H.; Lazier, J.R.N. Dynamics of Marine Ecosystems: Biological-Physical Interactions in the Oceans, 3rd ed.; Blackwell Publishing: Oxford, UK, 2006.

49. Šantić, D.; Kovačević, V.; Bensi, M.; Giani, M.; Vrdoljak Tomaš, A.; Ordulj, M.; Santinelli, C.; Šestanović, S.; Šolić, M.; Grbec, B. Picoplankton Distribution and Activity in the Deep Waters of the Southern Adriatic Sea. Water 2019, 11, 1655. [CrossRef]

50. Viličić, D.; Vučak, Z.; Škrivanić, A.; Gržetić, Z. Phytoplankton blooms in the oligotrophic open South Adriatic waters. Int. Symp. Chem. Mediterr. 1989, 28, 89-107. [CrossRef]

51. Kršinić, F. The family Xystonellidae (Ciliophora, Tintinnina) in the Adriatic Sea. J. Plankton Res. 1988, 10, 413-429. [CrossRef]

(C) 2019 by the authors. Licensee MDPI, Basel, Switzerland. This article is an open access article distributed under the terms and conditions of the Creative Commons Attribution (CC BY) license (http://creativecommons.org/licenses/by/4.0/). 